\title{
MODEL PEMBELAJARAN INTEGRATIF PADA BIOLOGI PERKEMBANGAN HEWAN: ANALISIS KEBUTUHAN PENGEMBANGAN
}

\author{
M. Haviz', Lufri², Ahmad Fauzan ${ }^{2}$, Z. Mawardi Effendi' \\ ${ }^{1}$ Program Studi Pendidikan Biologi STAIN Batusangkar, ${ }^{2}$ Universitas Negeri Padang \\ Korespondensi: Jln. Sudirman No. 137 Kuburajo Lima Kaum Batusangkar \\ e-mail: haviz80@yahoo.co.id
}

\begin{abstract}
The report is a part of developing integrative learning model (MPI) on the biology of animal development. The research objective was to determine the needs analysis of developing MPI on the biology of animal development at STAIN Batusangkar. The research use Plomp model. The data obtained will be analyzed by data reduction, data presentation and drawing conclusions. The result showed that philosophy of STAIN Batusangkar is an integration. Analysis of the characteristics of students showed that students of STAIN Batusangkar has a heterogeneous background of the aspects of capability. These results are based on the findings of the Academic Performance Index, schools and majors while undergoing studies in high school, the course pre-condition and the results of multiple intelegencie test. Developmental of biology material is characterized by the facts, concepts, principles and theories. In conclusion, the research is a part of activity that supports of developing MPI on the biology of animal development at STAIN Batusangkar.
\end{abstract}

Kata kunci: analisis karakteristik, model pembelajaran integratif, biologi perkembangan hewan

\section{PENDAHULUAN}

$\mathrm{P}$ eningkatan mutu pendidikan Perguruan Tinggi Agama Islam telah dilakukan oleh Direktorat Jenderal Pendidikan Tinggi Islam Kementerian Agama Republik Indonesia. Langkah yang dilakukan adalah mendukung alih status STAIN menjadi IAIN atau UIN. Saat ini, STAIN Batusangkar sedang mempersiapkan alih status dari sekolah tinggi menjadi institut. Untuk mendukung persiapan alih status tersebut, STAIN Batusangkar telah membuka dan menyelenggarakan beberapa program studi baru, seperti pendidikan biologi, pendidikan fisika dan program studi lainnya.
Menjadi program studi baru, pendidikan biologi belum memiliki perangkat, instrumen dan model pembelajaran yang baik dan maksimal. Belum baik dan maksimal diartikan dengan belum dilakukan kajian yang mendalam tentang pemilihan strategi yang sesuai dengan karakteristik Program Studi Pendidikan Biologi STAIN Batusangkar.

Berdasarkan hasil pengamatan, ditemukan beberapa situasi pendidikan di STAIN Batusangkar. Situasi pendidikan pertama, STAIN Batusangkar telah mengembangkan dan menggiatkan penerapan active learning dalam proses pembelajaran. Program ini telah dilaksanakan pada program studi lain di STAIN Batusangkar. Tujuannya adalah 
untuk membekali lulusan dengan kompetensi-kompetensi yang harus dikuasai oleh guru. Kompetensi tersebut adalah kepribadian, pedagogik, profesional dan sosial. STAIN Batusangkar sebagai salah satu institusi penghasil guru juga harus mampu mempersiapkan calon lulusan yang siap pakai (out comes) di sekolah, madrasah atau lembaga pendidikan lainnya. Oleh karena itu keterampilan dasar guru mutlak harus dikuasai oleh calon guru, misalnya keterampilan bertanya, memberi penguatan, mengadakan variasi, menjelaskan, membuka dan menutup pelajaran, membimbing diskusi kelompok kecil dan perorangan, mengelola kelas dan mengembangkan dan menggunakan media (Wardani dkk., 1999). Situasi pendidikan kedua, adanya temuan tidak baik aktifitas mahasiswa dalam proses pembelajaran. Rendahnya aktivitas mahasiswa dalam proses pembelajaran akan menyebabkan berkurangnya kualitas proses pembelajaran.

Kondisi-kondisi ini juga ditemukan di Program Studi Pendidikan Biologi STAIN Batusangkar. Situasi-situasi pendidikan diatas mengakibatkan rendahnya kualitas proses pembelajaran. Kondisi ini juga akan menyebabkan rendahnya hasil belajar mahasiswa. Lebih jauh, juga akan mempengaruhi kualitas dan keterpakaian lulusan di masyarakat (outcomes). Kondisi-kondisi tersebut dianggap masalah utama untuk diselesaikan oleh setiap tenaga kependidikan, seperti dosen yang mengajar di Program Studi Pendidikan Biologi di STAIN Batusangkar.

Menjadi program studi umum yang berada di Perguruan Tinggi Agama Islam (PTAI), pengembangan Program Studi Pendidikan Biologi harus disesuaikan dengan filosofis PTAI tersebut. Filosofis yang dikemukan dalam pengembangan PTAI saat ini adalah adanya keterpaduan keilmuan antara ilmu umum dan ilmu agama. Termasuk STAIN Batusangkar, yang juga menganut filosofis integrasi ilmu agama dan ilmu umum yang fleksibel dalam pengembangannya. Implikasinya, filosofis pengembangan ini harus mampu diterjemahkan oleh setiap tenaga pendidik dan kependidikan di STAIN Batusangkar. Salah satu bentuk implikasinya adalah melakukan kajian pengembangan keilmuan berbasis Al-Quran.

Materi biologi perkembangan hewan berciri fakta, konsep, prinsip dan teori. Karakteristik materi ini memerlukan pemahaman tinggi untuk menguasainya. Diduga rendahnya penguasaan materi akan menyebabkan rendahnya hasil belajar mahasiswa. Untuk mengatasinya, diperlukan kajian-kajian yang lebih mendalam untuk mengembangkan mata kuliah biologi perkembangan hewan. Beberapa hasil penelitian terdahulu telah meneliti

Terkait dengan pengembangan mata kuliah biologi perkembangan hewan, kajian pengembangannya telah dilakukan oleh peneliti sebelumnya. Misalnya penelitian yang telah dilakukan oleh Lufri $(2004 ; 2005)$ tentang eksperimen penggunaan problem solving dan peta konsep dalam pembelajaran. Penelitian ini dilakukan di Jurusan Biologi FMIPA Universitas Negeri Padang. Hasil penelitian menunjukkan bahwa hasil belajar mahasiswa menggunakan metode problem solving dan peta konsep lebih baik dari metode ceramah. Lufri dan Helendra (2009; 2011) juga telah mengembangkan materi pembelajaran Biologi Perkembangan Hewan untuk mendukung pelaksanaan proses pembelajaran. Nerita (2011) mengembangkan media CD interaktif berorientasi konstruktivisme di Program Studi Pendidikan Biologi STKIP PGRI Sumatera Barat. Haviz dkk. (2011a; 2011b) telah mengembangkan perangkat pembelajaran kooperatif dengan tingkat validitas baik pada mata kuliah Biologi Perkembangan Hewan di Program Studi Pendidikan Biologi STAIN Batusangkar. Selanjutnya, Haviz dan Maris (2012) telah mengembangkan CD interaktif berorientasi pembelajaran kooperatif pada Biologi Perkembangan Hewan. Hasilhasil kajian ini mengeksplorasi materi 
Biologi Perkembangan Hewan secara ilmiah dan tidak mengelaborasikannya dengan materi lain seperti ayat-ayat AlQuran. Sehingga, diperlukan kajian pengembangan berikutnya yang bersifat integratif.

Berdasarkan penjelasan-penjelasan diatas penting untuk dilakukan analisis awal tentang pengembangan model pembelajaran integratif pada biologi perkembangan hewan. Penelitian ini merupakan bagian dari penelitian pengembangan model pembelajaran integratif pada biologi perkembangan hewan di perguruan tinggi agama islam. Tujuan penenelitian adalah melakukan analisis kebutuhan pengembangan model pembelajaran integratif pada biologi perkembangan hewan. Sehingga proses desain model sesuai dengan prinsip-prinsip desain pengembangan model pembelajaran.

\section{METODE PENELITIAN}

\section{Desain Pengembangan}

Penelitian pengembangan ini menggunakan desain pengembangan Plomp (2010) pada tahap preliminary research. Pada preliminary research, peneliti melakukan analisis mendalam tentang materi dan masalah yang mendasari pentingnya untuk dilakukan pengembangan model pembelajaran integratif pada biologi perkembangan hewan.

\section{Prosedur Pengembangan}

Penelitian prelimanary research (penelitian pendahuluan) bertujuan untuk menganalisis masalah utama yang mendasari pentingnya pengembangan model pembelajaran integratif. Analisis kebutuhan penelitian ini didasari atas karakteristik institusi dan karakteristik mahasiswa serta analisis instruksional. Langkah-langkah yang dilakukan untuk ketiga tahap tersebut adalah:

\section{Analisis Karakteristik Institusi}

Analisis karakteristik institusi bertujuan melihat arah pengembangan instititusi di saat sekarang dan di masa datang. Analisis karakteristik institusi dilakukan dengan mengkaji visi, misi dan tujuan STAIN Batusangkar. Visi, misi dan tujuan tersebut diperoleh dari dokumen master plan STAIN Batusangkar 2010-2025. Untuk melengkapi perolehan data, dilakukan wawancara dengan Ketua STAIN Batusangkar periode 2002-2010. Instrumen yang digunakan pada penelitian ini adalah pedoman wawancara. Pertanyaan wawancara dikembangkan dari kata kunci yang dimuat pada visi STAIN Batusangkar. Kata kunci tersebut adalah integrasi. Aspek yang dijadikan indikator dan pertanyaan yang diajukan saat wawancara adalah (1) hakikat dan filosofis; (2) sejarah; (3) makna; (4) tujuan dan (5) implementasi.

\section{Analisis Karakteristik Mahasiswa}

Sumber data karakterisitik mahasiswa adalah dokumen dari Bagian Akademik dan Kemahasiswaan (Akama) STAIN Batusangkar dan hasil tes kecerdasan jamak (multiple inteligencie). Mahasiswa yang dianalisis adalah peserta mata kuliah biologi perkembangan hewan semester ganjil 2011/2012 dengan jumlah 48 orang. Karakteristik mahasiswa tersebut meliputi skor indeks prestasi kumulatif (IPK), asal sekolah dan jurusan di sekolah menengah atas dan nilai mata kuliah prasyarat (struktur hewan). Kecerdasan jamak (multiple inteligence) mahasiswa diperoleh dari hasil tes. Instrumen yang digunakan adalah instrumen standar dari Unit Pelaksana Teknis Layanan Bimbingan Konseling (UPTLBK) STAIN Batusangkar. Materi tes kecerdasan jamak (multiple inteligence) meliputi delapan aspek yaitu verbal, numerikal, visual, kinestetik, musik, intrapersonal, interpersonal dan natural (Gardner, 1999) 
Kumpulan data ini digunakan untuk melihat tingkat keberagaman kemampuan mahasiswa.

\section{Analisis Karakteristik Instruksional}

Analisis instruksional diawali dengan melakukan analisis tujuan pembelajaran. Hasil analisis akan memperlihatkan tujuan dan arah pengembangan mata kuliah biologi perkembangan hewan. Hasil analisis ini diuraikan dalam analisis instruksional, standar kompetensi, kompetensi dasar, indikator dan tujuan pembelajaran dan materi pembelajaran. Materi kuliah biologi perkembangan yang digunakan adalah buku biologi perkembangan hewan jilid 1 yang ditulis oleh Lufri dan Helendra (2009).

\section{Teknik Analisis Data}

Secara umum, data yang diperoleh pada penelitian ini adalah data kualitatif dan kuantitatif. Data kualitatif dianalisis dengan mengikuti langkah-langkah yang dituliskan oleh Miles dan Huberman (1984) dalam Sugiyono (2007: 337). Langkah-langkah tersebut adalah (a) reduksi data; (b) penyajian data dan (c) penarikan kesimpulan.

\section{HASIL DAN PEMBAHASAN}

\section{Analisis Karakteristik Institusi}

Karakterisitik STAIN Batusangkar dianalisis dari paparan visi, misi dan tujuan lembaga pendidikan ini. Di bawah ini dituliskan cuplikan visi, misi dan tujuan STAIN Batusangkar yang dikutip dari Dokumen Master Plan STAIN Batusangkar 2010-2025 (2010:5-8).

Visi bagi Sekolah Tinggi Agama Islam Negeri (STAIN) Batusangkar "... maka wujud visi yang ingin dicapai STAIN Batusangkar pada tahun 2025 adalah menjadi World Class University yang Unggul, Terpercaya, dan Berbudaya. Visi STAIN Batusangkar tahun 2025 ini sejalan dengan konsep pengem- bangan STAIN Batusangkar menjadi town university...".

Mengacu kepada visi tersebut, disusunlah misi implementatif dan dimuat dalam Dokumen Master Plan STAIN Batusangkar 2010-2025 (2010:67). Paparan beberapa Misi STAIN Batusangkar yang berkaitan dengan penelitian ini adalah:

1) Menguasai, mengembangkan dan memanfaatkan ilmu pengetahuan, teknologi, dan seni yang bernafaskan Islam dengan mewujudkan fakultas-fakultas, jurusan-jurusan, program studi-program studi, penelitian, pembinaan kelembagaan serta pengelolaan sumber daya manusia akademik secara berdaya guna dan berhasil guna.

2) Menguasai dan mengembangkan kombinasi dan integrasi "Ilmu Agama" dan "Ilmu Umum" (sosial, eksakta, dan humaniora) yang berdasarkan al-Quran dan Sunnah melalui penguasaan Bahasa Arab dan Bahasa Inggris yang tertuang dalam kurikulum dengan dukungan dosen yang profesional dan proporsional serta sarana dan prasarana yang kondusif.

3) Membentuk insan akademik yang concern terhadap berbagai kajian keislaman dan budaya lokal.

4) Meningkatkan kualitas keimanan, ibadah, akhlak, intelektual, hasil karya dan kehidupan yang setara bagi dosen dan karyawan.

5) Penerapan otonomi keilmuan untuk mendorong pengembangan fakultas/jurusan/program studi dalam melaksanakan tugasnya sebagai pengembangan ilmu pengetahuan dan teknologi serta meningkatkan kualitas dan kuantitas dan diverifikasi bidang penelitian.

6) Pengembangan kurikulum dan pembelajaran aktif dan efektif dalam berbagai kelompok bidang mata kuliah. 
Mengacu kepada tujuan pokok dalam Dokumen Master Plan STAIN Batusangkar 2010-2025 (2010:8), ditemukan beberapa tujuan pokok terkait dengan penelitian ini. Tujuan pokok tersebut adalah

1) Menyiapkan peserta didik menjadi anggota masyarakat yang memiliki kemampuan akademik dan/atau profesional yang dapat menerapkan, mengembangkan, dan/atau menciptakan ilmu keIslaman.

2) Mengembangkan dan menyebarluaskan ilmu keIslaman, serta mengupayakan penggunaan untuk meningkatkan taraf kehidupan masyarakat dan memperkaya kebudayaan nasional.

3) Menghasilkan penelitian ilmuilmu keIslaman, budaya, dan teknologi.

Untuk mengkaji dan melengkapi bedah visi, misi dan tujuan pengembangan STAIN Batusangkar, penulis telah melakukan wawancara. Informan yang dipilih adalah Ketua STAIN Batusangkar periode 2002-2010. Aspek pertanyaan wawancara difokuskan kepada kata "integrasi". Cuplikan pertanyaan dan jawaban wawancara dinarasikan di bawah ini.

Peneliti: Bagaimana Hakikat atau Filosofis Visi STAIN Batusangkar?

Nara Sumber: Merupakan sasaran dan tujuan yang jelas dan harus dilaksanakan oleh STAIN Batusangkar ke masa datang. Visi ini akan memberikan nuansa spesifik dan menjadi identitas kelembagaan. Sehingga relatif berbeda dengan lembaga pendidikan tinggi lainnya. Visi ini digunakan sebagai antisipatif terhadap perkembangan filsafat ilmu saat ini yaitu adanya integrasi keilmuan, namun tetap berada dalam koridor peradaban islam yang ditopang dengan manajemen cerdas.

Peneliti: Bagaimana sejarah dan tujuan pembuatan Visi STAIN Batusangkar?

Nara Sumber: Secara filosofis, STAIN Batusangkar memperlihatkan konsep ilmu yang esensial dalam islam esensial. Sehingga akan muncul islam rahmatan lil 'alamin, mampu bertahan (survive) dan menjawab segala permasalahan dengan adanya integrasi keilmuan. Secara pragmatis, STAIN Batusangkar ingin berkembang lebih baik. STAIN Batusangkar berkembang tidak dibatasi dalam kerangka Sekolah Tinggi saja, dan akan berkembang dan berubah menjadi Universitas. Hal ini dilakukan untuk menyahuti kebutuhan umat islam yang semakin kompleks dan global.

Peneliti: Apakah maksud kata integrasi dalam Visi STAIN Batusangkar?

Nara Sumber: Memadukan dan adanya keterkaitan antara ilmu umum dengan islam yang selama ini ditempatkan secara dikotomi. Hal tersebut akan tergambar dalam kurikulum program studi yang ada di STAIN Batusangkar.

Peneliti: Apakah hakikat/filosofis integrasi dalam Visi STAIN Batusangkar?

Nara Sumber:Tidak adanya dikotomi keilmuan (umum dan agama) dalam islam

Peneliti: Apakah tujuan integrasi dalam Visi STAIN Batusangkar?

Nara Sumber:Dalam perkembangan ilmu akan lahir konsep ilmu yang memadukan ilmu umum dan agama yang ditempatkan selama ini secara terpisah. Dalam konteks ini, STAIN Batusangkar akan memadukan keduanya untuk melahirkan para praktisi, ilmuan atau lulusan yang memiliki wawasan, keterampilan dan sikap yang terintegrasi.

Peneliti: Bagaimana implementasi integrasi dalam Pengembangan STAIN Batusangkar di Bidang:

1. Akademik, terutama dalam pembelajaran oleh dosen sebagai tenaga pendidik dan pengembangan program studi?

2. Administrasi dan Keuangan, terutama oleh karyawan sebagai Tenaga Kependidikan?

3. Kemahasiswaan, terutama dalam pengembangan kemahasiswaan?

Nara Sumber:

1. Implementasi integrasi dalam Pengembangan STAIN Batusangkar di Bidang Akademik, terutama dalam pembelajaran oleh dosen sebagai tenaga pendidik dan pengembangan program studi adalah

a. Menyusun kurikulum yang sesuai dengan konsep-konsep integratif, misalnya memberikan penamaan (nomenclature) mata kuliah yang akan dijadikan objek. Misalnya mata kuliah Tafsir Tarbawi menjadi Tafsir Tarbawi Biologi.

b. Melakukan analisis komponen proses pembelajaran secara komprehensif, terutama dari aspek materi (content) 
dan penggunaan strategi pembelajaran yang relevan. Misalnya menggunakan metode tafsir maudhu'i dalam menganalisis materi (content) mata kuliah embriologi. Hal ini dilakukan dan menjadi tanggungjawab dosen yang program studi yang bersangkutan.

c. Membenahi instrumen-instrumen institusi sesuai dengan visi STAIN Batusangkar.

d. Melakukan aktivitas tri dharma perguruan tinggi sesuai dengan visi STAIN Batusangkar, misalnya melakukan penelitian dan pengabdian yang bernuansa integratif.

2. Implementasi integrasi dalam Pengembangan STAIN Batusangkar di Bidang Administrasi dan Keuangan, terutama oleh karyawan sebagai Tenaga Kependidikan adalah:

a. Melakukan aktivitas administrasi yang sesuai dengan aturan keuangan, jujur, transparansi serta efisien dalam pemanfaatan keuangan.

b. Tidak melakukan tindak korupsi, kolusi dan nepotisme (KKN) dalam kegiatan proyek.

c. Bersikap disiplin, ramah dan santun dalam melakukan pelayanan publik.

3. Implementasi integrasi dalam Pengembangan STAIN Batusangkar di Bidang Kemahasiswaan, terutama dalam pengembangan kemahasiswaan adalah

a. Menampilkan sikap-sikap yang islami dalam kehidupan sehari-hari.

b. Mendorong mahasiswa untuk melakukan kegiatan-kegiatan yang bersifat integratif. Misalnya melakukan nilainilai islami, edukasi dan dakwah dalam setiap kegiatan kemahasiswaan.

Menurut penulis keunggulan, terpercaya dan berbudaya yang dituliskan di visi tersebut tersebut memiliki ruang lingkup yang luas. Penulis menganalisis beberapa aspek tersebut, yaitu:

1. Keunggulan, terpercaya dan berbudaya bisa diartikan dengan STAIN Batusangkar sebagai universitas yang berperingkat dan bereputasi baik.

2. Keunggulan, terpercaya dan berbudaya bisa diartikan dengan STAIN Batusangkar sebagai universitas yang memiliki kekhasan yang tidak dimiliki oleh universitas atau perguruan tinggi lainnya.

3. Keunggulan, terpercaya dan berbudaya bisa diartikan dengan STAIN Batusangkar sebagai universitas yang mampu dan menguasai disiplin-disiplin ilmu yang dikembangkan.

4. Keunggulan, terpercaya dan berbudaya bisa diartikan sebagai universitas yang memiliki akreditasi program studi dan institusi yang baik.

5. Keunggulan, terpercaya dan berbudaya bisa diartikan sebagai universitas yang memiliki keterlibatan dalam penyelesaian-penyelesaian masalah di tingkat lokal, regional, nasional dan internasional.

Pada karakteristik institusi, ditelaah visi, misi dan tujuan STAIN Batusangkar sebagai lembaga pendidikan. Berdasarkan uraian visi tersebut, terlihat jelas arah pengembangan STAIN Batusangkar akan menjadi universitas yang unggul, terpercaya dan berbudaya. Terkait dengan penelitian ini, model pembelajaran integratif yang dikembangkan, diharapkan akan menjadi salah satu bagian dan bentuk keunggulan, terpercaya dan berbudaya tersebut.

Pada bagian berikut ini, dilakukan telaah terhadap misi STAIN Batusangkar. Misi implementatif ini merupakan indikator-indikator dalam peningkatan mutu, relevansi dan daya saing perguruan tinggi. Menurut peneliti, misi implementatif tersebut sangat erat kaitannya dengan penelitian ini. Beberapa argumentasi peneliti terkait dengan penelitian pengembangan model pembelajaran integratif dengan misi implementatif tersebut adalah:

1. Penelitian pengembangan model pembelajaran integratif yang telah dilakukan merupakan aplikasi dari pengembangan dan pemanfaatan ilmu pengetahuan dan teknologi teknologi pembelajaran untuk me- 
wujudkan program studi program studi yang islami.

2. Penelitian pengembangan model pembelajaran integratif yang telah dilakukan merupakan bentuk pengembangan kombinasi dan integrasi Ilmu Agama dan Ilmu Umum.

3. Penelitian pengembangan model pembelajaran integratif yang telah dilakukan merupakan bentuk kajian yang concern terhadap budaya lokal dan islam.

4. Penelitian pengembangan model pembelajaran integratif yang telah dilakukan diharapkan mampu meningkatkan kualitas keimanan, ibadah, akhlak, intelektual, hasil karya dan kehidupan yang setara bagi dosen dan dan mahasiswa.

5. Penelitian pengembangan model pembelajaran integratif yang telah dilakukan merupakan bagian dari bentuk pengembangan kurikulum dan pembelajaran aktif dan efektif dalam berbagai kelompok bidang mata kuliah.

Pada bagian berikut ini, juga telah ditelaah tujuan pokok STAIN Batusangkar sebagai lembaga pendidikan. Menurut peneliti, ketiga tujuan pokok tersebut sangat terkait dengan penelitian pengembangan model yang dilakukan. Beberapa argumentasi peneliti adalah

1. Penelitian pengembangan model pembelajaran integratif ini didesain untuk mempersiapkan mahasiswa untuk memiliki keterampilan-keterampilan yang menunjang profesi mereka di kemudian hari. Misalnya adanya intervensi keterampilan integratif saat pembelajaran dilakukan.

2. Penelitian pengembangan model pembelajaran integratif ini merupakan penelitian yang mengaplikasikan integrasi keilmuan.

Menurut penulis, berdasarkan uraian jawaban wawancara tersebut bisa dituliskan bahwa pengembangan model pembelajaran integratif penting dilaku- kan oleh setiap dosen di STAIN Batusangkar. Banyak aspek dan manfaat yang akan dirasakan dengan adanya pengembangan model ini, misalnya (1) dengan melakukan pengembangan model integratif akan memenuhi tuntutan aspek pengembangan kampus STAIN Batusangkar; (2) hasil penelitian pengembangan model pembelajaran integratif akan menjadi ciri khas STAIN Batusangkar.

\section{Karakteristik Mahasiswa}

Keempat sumber data tentang karakteristik mahasiswa yaitu indeks prestasi kumulatif (IPK), nilai struktur hewan, asal sekolah dan jurusan saat sekolah serta tes kecerdasan jamak memperlihatkan bahwa mahasiswa STAIN Batusangkar memiliki latar belakang dan kemampuan yang heterogen. Misalnya, temuan nilai Indeks Prestasi Akademik (IPK) memperlihatkan hanya $16.67 \%$ mahasiswa yang memiliki IPK diatas 3.5 dan $41.67 \%$ mahasiswa yang memiliki IPK dengan rentang 3.01-3.51. Sedangkan sisanya berada dibawah 3.00. IPK mahasiswa memperlihatkan lebih dari $75 \%$ mahasiswa telah menguasai kompetensi mata kuliah yang telah mereka pelajari selama menjalani studi di STAIN Batusangkar.

Hasil yang sama ditemukan pada nilai struktur hewan (mata kuliah pra syarat) juga memperlihatkan hasil yang sama. Nilai mahasiswa tersebar secara tidak merata di setiap range nilai. Hasil penelitian tentang nilai struktur hewan mahasiswa memperlihatkan bahwa tingkat penguasaan mahasiswa terhadap materi pembelajaran yang berciri fakta, konsep, proses dan teori beragam dan rendah. Sehingga bisa disimpulkan penguasaan standar kompetensi dan kompetensi dasar mata kuliah ini juga beragam dan rendah.

Jika dilihat dari asal sekolah dan jurusan saat sekolah, mahasiswa juga berasal dari berbagai sekolah dan jurusan yang beragam. Hasil penelitian tentang 
asal dan jurusan mahasiswa di Sekolah Menengah Atas/Sederajat memperlihatkan bahwa asal sekolah dan jurusan mahasiswa saat melakukan studi di tingkat menengah atas heterogen.

Untuk mengetahui minat dan bakat, dilakukan tes kecerdasan jamak terhadap mahasiswa peserta mata kuliah ini. Hasil tes juga memperlihatkan bahwa bahwa tidak semua mahasiswa yang berbakat di bidang ke-alam-an (natural). Meskipun tidak berbeda jauh, nilai hasil tes kecerdasan natural berada di posisi ke tiga. Hasil penelitian tentang kecerdasan jamak mahasiswa memperlihatkan bahwa tidak semua mahasiswa yang berbakat di bidang ke-alam-an (natural). Meskipun tidak berbeda jauh, nilai hasil tes kecerdasan natural berada di posisi ke tiga.

Sehingga bisa disimpulkan, analisis karakteristik mahasiswa memperlihatkan bahwa mahasiswa STAIN Batusangkar memiliki latar belakang yang heterogen dari aspek kemampuan. Hasil ini didasari atas temuan nilai Indeks Prestasi Akademik (IPK), asal sekolah dan jurusan saat menjalani studi di sekolah menengah atas, nilai mata kuliah pra syarat (struktur hewan) dan hasil tes kecerdasan jamak (multiple intelegencie test).

\section{Karakteristik Instruksional Biologi Perkembangan Hewan}

Biologi Perkembangan Hewan adalah mata kuliah keilmuan dan keterampilan (MKK 1924). Mata kuliah ini merupakan mata kuliah wajib dengan bobot 3 SKS (1). Materi mata kuliah ini berkaitan dengan materi mata kuliah lain di biologi seperti Biologi Umum, Biologi Sel, Genetika dan Struktur Hewan.

Standar kompetensi mata kuliah biologi perkembangan hewan adalah mahasiswa mampu memahami konsep dasar dan proses perkembangan individu serta memahami kebesaran Allah SWT berdasarkan proses penciptaan manusia. Kompetensi dasarnya adalah mahasiswa mampu menganalisis prinsip-prinsip perkembangan, menganalisis spermatogenesis, menganalisis ogenesis, menganalisis fertilisasi, menganalisis proses pembelahan dan blastulasi, menganalisis gastrulasi dan menganalisis proses penciptaan manusia dalam Al-Quran. Analisis instruksional Biologi Perkembangan Hewan ditampilkan pada Gambar 1.

Analisis materi kuliah biologi perkembangan hewan menunjukkan bahwa karakteristik materi mencakup fakta, prinsip dan teori. Hal ini bisa dilihat pada ringkasan uraian materi spermatogensis. Misalnya pada kutipan materi berikut.

"Spermatogenesis berlangsung dalam tubulus seminiferus testis. Pada tubulus ini terdapat dua tipe sel yang penting, yaitu sel benih (germ cell) dan sel-sel sertoli. Sel sertoli berperan memberi makan sperma sel-sel sperma yang sedang berkembang. Pada beberapa hewan vertebrata, termasuk manusia, spermatogonia terletak di bagian dalam dinding tubulus atau dekat lamina basalis. Dalam perkembangannya, sel-sel spermatogonia bergerak menuju lumen tubulus seminiferus hingga terbentuk sperma (Lufri dan Helendra, 2009:19). 


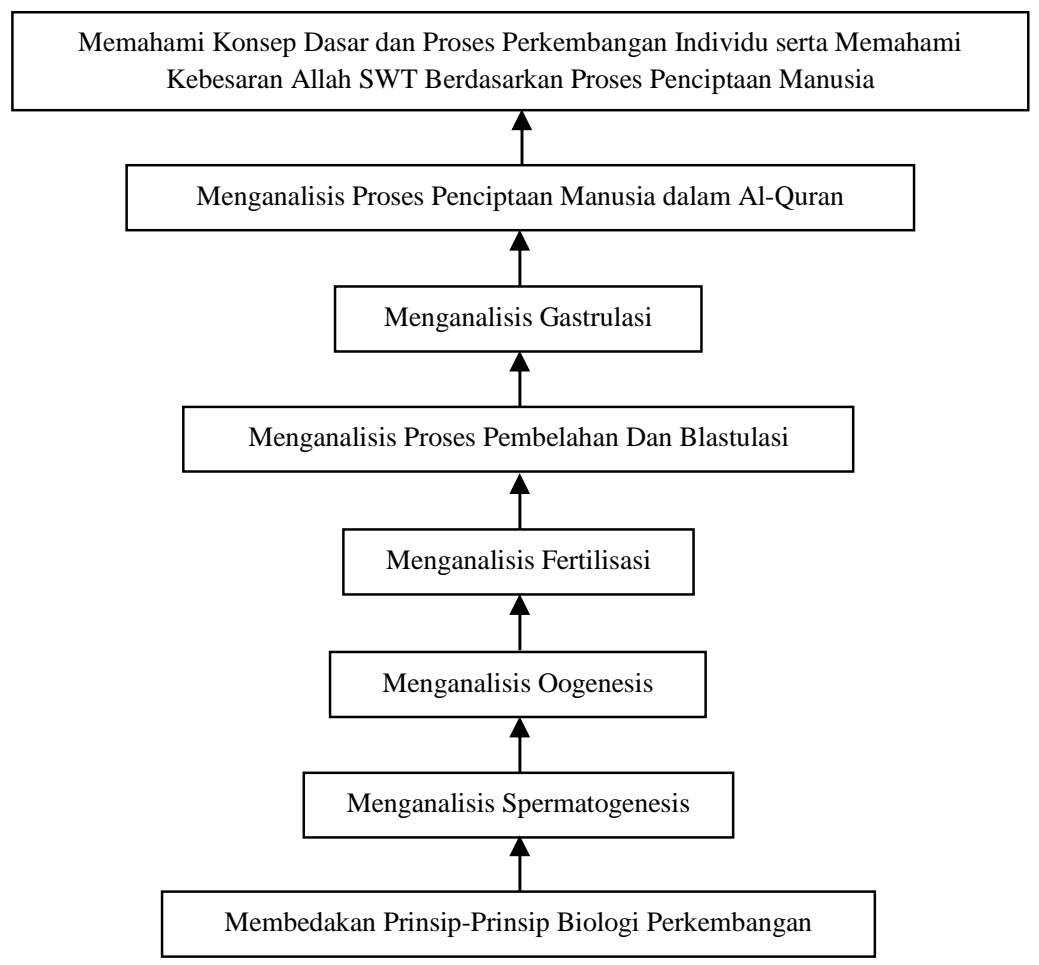

Gambar 1 Analisis Instruksional Biologi Perkembangan Hewan

Kutipan materi-materi tersebut berturut-turut, sehingga menghasilkan memperlihatkan adanya materi yang spermatosit primer, (2) meiosis, pada berciri proses. Proses terlihat dari ka- fase ini, spermatosit mengalami dua kali limat berikut, "spermatogenesis terbagi pembelahan secara berturut-turut atas tiga fase yaitu: (1) sperma- (meiosis I dan II). Proses proliferasi atau tositogenesis, pada fase ini, sperma- perbanyakan sel spermatogonia ditogonia membelah (secara mitosis) tunjukkan pada Gambar 2.

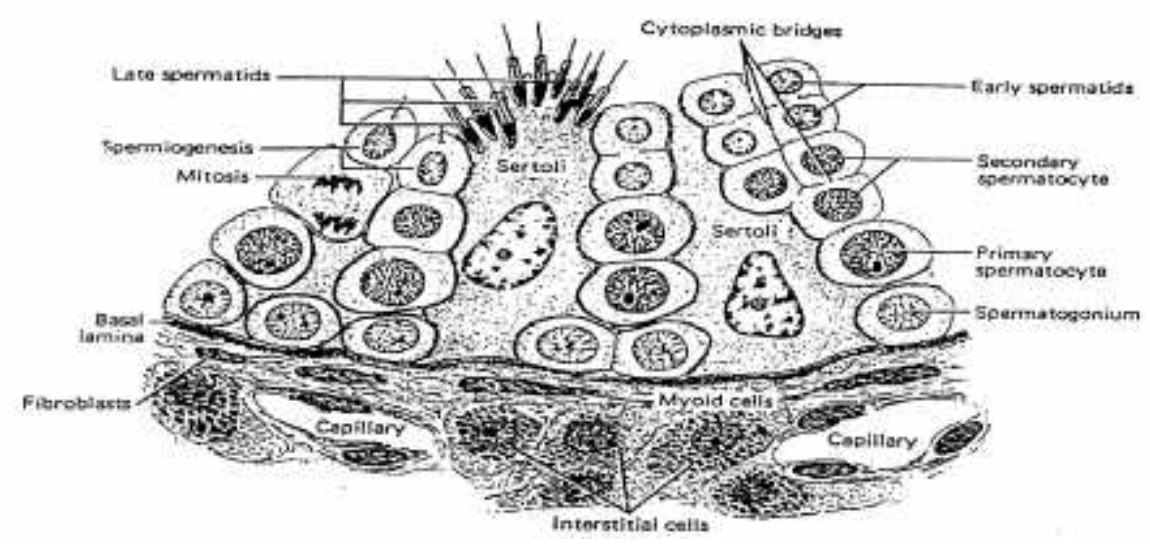

Gambar 2 Diagram struktur bagian tubulus seminiferus dan jaringan interstitial (Junquera dan Carneiro, 1980: 446).

Materi biologi perkembangan juga bercirikan konsep. Cuplikan materi berciri konsep tersebut ditampilkan pada beberapa paragraf berikut.
Pada spermatogenesis, proses pematangan spermatozoa terjadi di epididymis (Gambar 3 dan 4). Spermatozoa yang matang merupakan sel yang 
sangat khas, dimana inti dikemas sangat padat dengan akrosom terdapat di daerah apikal dekat inti dan mitokondria tersusun dalam bentuk spiral di sekeliling pangkal flagel (Garner dan Hafez, 2000).
Sel spermatozoa diproduksi, kemudian meninggalkan testes belum mampu untuk membuahi sehingga diperlukan tahapan pematangan dalam epididymis (Visconti dkk., 1995).

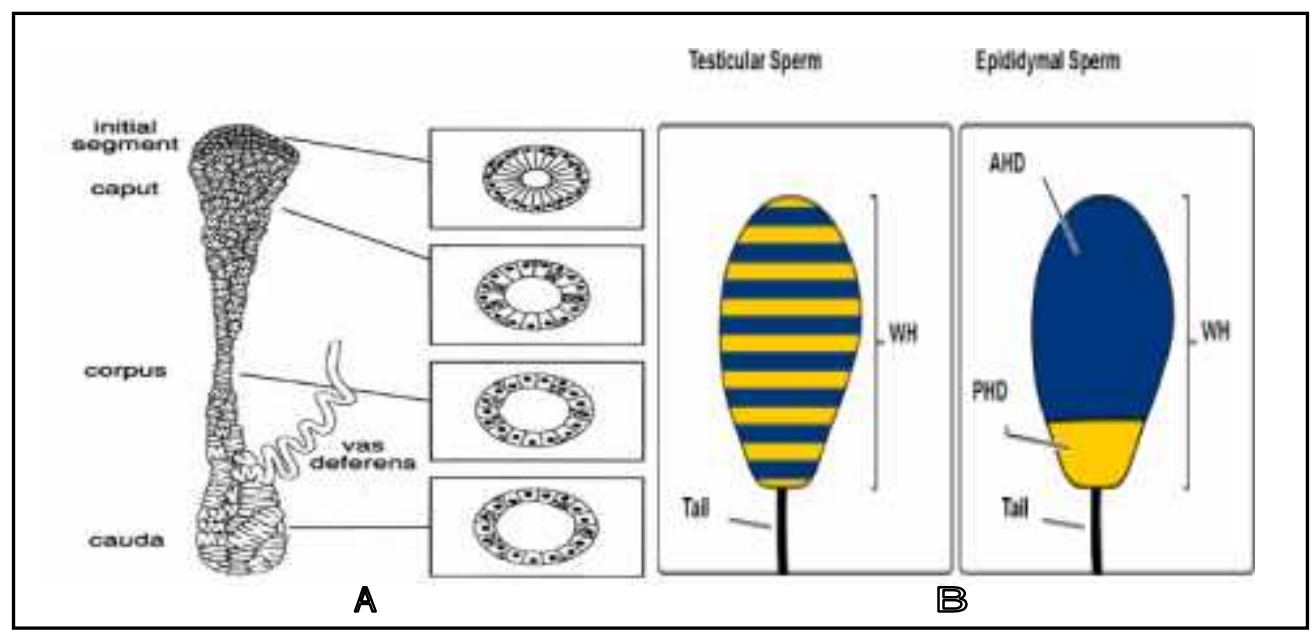

Gambar 3. Diagram Epididymis. A Epididymis dan bagian-bagiannya, B spermatozoa Testes (kiri) dan epididymis (kanan) (Hunnicut dkk., 2004).

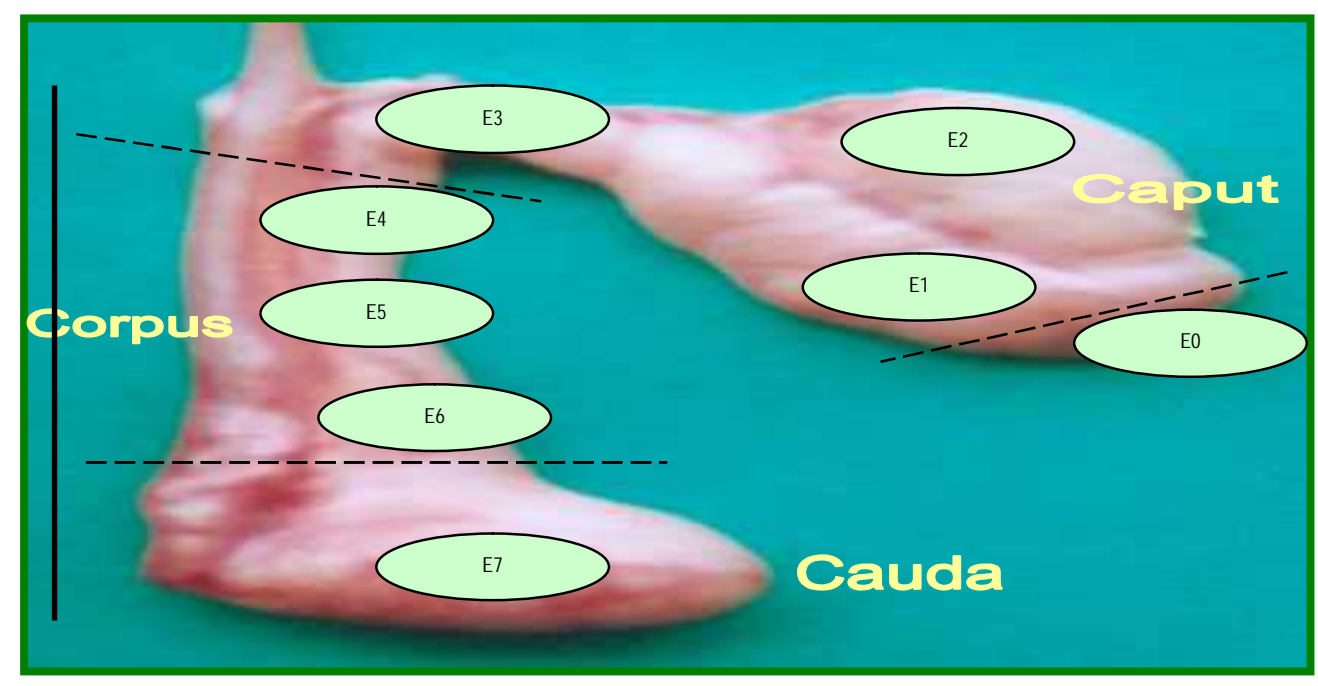

Gambar 4. Epididymis domba. E0: initial segment, E1: proximal caput, E2: middle caput, E3: distal caput, E4: proximal corpus, E5 : middle corpus, E6: distal corpus, E7: cauda. E:Epididymis, Bar: 9,5 cm (Haviz dkk., 2007a; Haviz, 2007b; Haviz, 2007c).

Pada tahap spermiogenesis terjadi perubahan topografi di dalam sel spermatid yang terdiri dari empat fase yaitu golgi, tudung, akrosom dan maturasi. Pada proses ini, inti akan menjadi padat dan bagian kepala spermatozoa dikelilingi oleh sedikit sitoplasma, selanjutnya sebagian besar sitoplasma bergerak ke arah ekor, dan kompleks golgi mensintesis akrosom di daerah apikal kepala, sedangkan di daerah ekor sentriol anterior menjadi titik awal untuk perkembangan flagel dan sentriol posterior membentuk suatu cincin yang mengelilingi pangkal flagel (Jhonson dan Everit, 1995).

Proses pematangan spermatozoa juga diiringi dengan terjadinya serangkaian perubahan komposisi atau materi spermatozoa, misalnya perubahan 
jumlah dan keberadaan protein khususnya pada membran kepala spermatozoa. Proses ini disebut dengan polarisasi protein. Polarisasi protein diperlukan dalam perubahan morfologi dan fungsi spermatozoa (Hunnicut dkk., 1997). Pada proses ini, protein membran kepala spermatozoa akan bersegregasi dari anterior head domain (AHD) atau posterior head domain (PHD) dan ditemukan ketika spermatozoa sesaat meninggalkan testes (Hunnicut dkk., 2004). Faktor-faktor yang mempengaruhi polarisasi protein membran spermatozoa adalah interaksi protein dengan sitoskleton, interaksi protein dengan matriks ekstraseluler dan peningkatan fluiditas lipid bilayer (Hunnicut dkk., 1997).

Hasil penelitian memperlihatkan bahwa membran spermatozoa sebelum bercampur dengan ejakulat masih memiliki materi penting ketika di bagian cauda epididymis. Hasil penelitian (Kohane dkk., 1987) memperlihatkan Struktur membran spermatozoa masih diliputi oleh banyak zat seperti protein, karbohidrat, lipid dan materi lain. Pelepasan sebagian materi ini dari permukaan membran spermatozoa merupakan bagian penting dalam kapasitasi (Visconti dkk., 1995). Sel-sel epitel epididymis aktif mensekresikan cairan yang dibutuhkan spermatozoa selama berada di epididymis (Setchell dkk., 1994) seperti untuk perubahan spermatozoa (Hammerstedt dan Parks, 1987) dan mencegah terjadinya reaksi akrosom dini di epididymis dan sesaat setelah ejakulasi (Hunter dkk., 1978).

Materi biologi perkembangan juga bercirikan fakta. Cuplikan materi berciri fakta tersebut ditampilkan pada beberapa paragraf berikut.

Hasil penelitian lain, memperlihatkan bahwa materi spermatogenesis bersifat fakta adalah spermatozoa yang diproduksi di tubuli seminiferi testes, akan mengalami serangkaian proses pematangan saat perjalanan di epi- didymis (Bredford, 1975). Misanya, terjadi interaksi antar spermatozoa dan antara spermatozoa dengan sel-sel epitel epididymis (Hammerstedt dan Parks, 1987). Pada saat pematangan, spermatozoa memperoleh kemampuan bergerak dan kemampuan untuk membuahi dari protein epididymis. Diantara kelompok protein tersebut adalah protein pengikat sperma-sel telur (sperm-egg binding proteins) (Yanagimachi, 1994) dan protein yang berperan pada aglutinasi antar spermatozoa (Dacheux dkk., 1983). Dilaporkan efek aglutinasi menurun pada bagian cauda epididymis sebelum sperma diejakulasikan (Dacheux dan Dacheux, 1988). Hal ini diduga akibat adanya komponen protein lain yang bersifat sebagai anti-aglutinin (Harayama dkk., 1994; Haviz dkk., 2008).

Kedua paragraf diatas memperlihatkan bahwa karakteristik materi ini berkarakteristik fakta. Karena temuantemuan penelitian tersebut memperlihatkan bahwa materi perkuliahan ini memperlihatkan adanya fakta hasil penelitian, adanya konsep dan teori baru dari hasil penelitian tersebut. Misalnya pada kalimat-kalimat berikut, pada kalimat pertama dituliskan "hasil penelitian yang memperlihatkan bahwa membran spermatozoa sebelum bercampur dengan ejakulat memiliki materi penting dan kalimat". Kalimat kedua dituliskan "sel-sel epitel epididymis aktif mensekresikan cairan yang dibutuhkan spermatozoa selama berada di epididymis”. Kalimat ketiga dituliskan "interaksi antar spermatozoa dan antara spermatozoa dengan sel-sel epitel epididymis".

\section{PENUTUP}

Berdasarkan paparan pembahasan tentang analisis kebutuhan model pembelajaran integratif, dituliskan beberapa simpulan: 
1. STAIN Batusangkar adalah salah satu Lembaga Pendidikan dan Tenaga Kependidikan (LPTK) di Sumatera Barat. LPTK ini mempunyai visi terwujudnya lembaga perguruan tinggi yang mampu menyahuti kebutuhan umat dan tuntutan dunia kerja berdasarkan integrasi dan kombinasi Ilmu Agama dan Ilmu Umum yang ditopang dengan manajemen yang cerdas, profesional dan modern. Misinya implementatif mewajibkan adanya integrasi keilmuan dalam semua bidang pengembangan institusi dimasa sekarang dan masa datang. Sehingga, pengembangan STAIN Batusangkar sebagai LPTK memiliki filosofis integrasi, termasuk dalam pengembangan proses pembelajaran.

2. Paparan misi implementatif dan tujuan pokok STAIN Batusangkar menggambarkan pentingnya dilakukan kajian dan penelitian yang mendukung pelaksanaan misi dan tujuan tersebut. Penelitian pengembangan model pembelajaran integratif ini merupakan salah satu bentuk kegiatan tersebut.

3. Paparan hasil wawancara menggambarkan dan mendukung pelaksanaan integratif dalam pengembangan akademik. Integrasi dalam pengembang-

\section{DAFTAR RUJUKAN}

Bredford, J. M. 1975. Maturation, transit and fate of spermatozoa in the epididymis in Aswood EB and Greep RO, Eds. Handbook of Physiology. Washington DC: Physiology Society.

Dacheux, E., and Dacheux, J. L. 1988. Immunocytochemical localization of anti-aglutinin in boar epididymis. Cell Tissue Res 252: 329-337. an akademik tersebut direalisasikan dalam proses pembelajaran.

4. Analisis instruksional memperlihatkan bahwa standar kompetensi mata kuliah perkembangan hewan adalah mahasiswa memahami konsep dasar dan proses perkembangan individu serta memahami kebesaran Allah SWT berdasarkan proses penciptaan manusia. Kompetensi Dasar adalah mahasiswa mampu menganalisis prinsip-prinsip perkembangan, menganalisis spermatogenesis, menganalisis oogenesis, menganalisis fertilisasi, menganalisis proses pembelahan dan blastulasi, menganalisis gastrulasi dan menganalisis proses penciptaan manusia dalam Al-Quran.

5. Materi pembelajaran biologi perkembangan hewan bercirikan fakta, konsep, prinsip dan teori.

\section{UCAPAN TERIMA KASIH}

Penelitian ini adalah bagian dari penelitian disertasi yang dibiayai oleh dana BPPS dari Dirjen Dikti. Peneliti mengucapkan terima kasih atas bantuan pembiayaan penelitian ini. Peneliti juga menyampaikan ucapan terima kasih tim validator, kontributor dan pihak lain yang telah membantu terlaksananya penelitian.

Dacheux, J. L., Paquignon, M., and Combarnous, Y. 1983. Head-tohead agglutination of ram and boar epididymal spermatozoa and evidence for an epididymal antiaglutinin. J Reprod Fertil 67: 181189.

\footnotetext{
Dokumen Master Plan STAIN Batusangkar 2010-2025. STAIN Batusangkar. Tidak Dipublikasikan.
} 
Gadner, H. 1999. Intelligence reframed: Multiple intelligencies for $21^{\text {st }}$ century. New York: Basic Book.

Garner DL dan Hafez ESE. 2000. Spermatozoa and seminal plasma. In: Hafez B, Hafez ESE, editor. Reproduction in Farm Animals, $7^{\text {th }}$ $E d$. South Caroline: Lippincot Williem and Wilson: 96-109.

Hammerstedt, R. H., and Parks, J. E. 1987. Changes in sperm surface associated with epididymal transit. J Reprod Fertil Suppl 34: 133-149.

Haviz M, Lufri, Helendra dan Ramadhan S. 2011a. Pengembangan Perangkat Model Pembelajaran Kooperatif Pada Biologi Perkembangan Hewan. Makalah Seminar Nasional dan Mubes Iluni III Biologi FMIPA UNP. Padang Panjang, 26-27 Februari 2011.

Haviz, M. 2007b. Fenomena aglutinasi spermatozoa pada mamalia. Jurnal Forum Wacana UNJA. Vol (2): 13-24.

Haviz, M. 2007c. Kajian aglutinasi spermatozoa: sebaran antiaglutinin dan karakterisasi plasma yang dikoleksi dari epididymis dan ejakulat domba. Jurnal Akademika 11 (1): 100-107.

Haviz, M., Agungpriyono, S., Fahrudin, M., Setiadi, M. A., dan Boediono, A. 2007a. Sebaran antiaglutinin spermatozoa dalam plasma yang dikoleksi dari epididymis dan ejakulat domba. Jurnal Veteriner 8 (1): 24-31.

Haviz, M., dan Maris, I. M. 2012. Pengembangan CD Interaktif Berorientasi Pembelajaran Kooperatif Pada Biologi Perkembangan Hewan. Prosiding Penelitian Dosen STAIN Batusangkar 2011. (accepted)

Haviz, M., Lufri., Helendra., dan Ramadhan, S. 2011b. Pengem- bangan Perangkat Model Pembelajaran Kooperatif Pada Biologi Perkembangan Hewan. Jurnal Ilmiah Ta'dib Vol 14 No. 1: 7-15 (Sebagian isi, sudah dipublikasikan sebelumnya).

Hunnicut, G., Ann C., and Dennis, K. 2004. Reproductive biology and immunology sperm maturation. University of connecticuty health center United States. Population Briefs Vol 5, No 2.

Hunnicut, G., Koppel, D. E., Myles, D. G. 1997. Analysis of the process of localization of fertilin to the sperm posterior head plasma membrane domain during sperm maturation in the epididymis. Dev Biol 191: 146159.

Hunter, R. H. F., Holtz, W., and Hermann, H. 1978. Stabilizing role of epididymal plasma in relation to the capacitation time of boar spermatozoa. Anim Reprod Scie 1: 161-166.

Iska, Syukri. 2011. Wawancara Tentang Analisis Visi dan Misi STAIN Batusangkar Tanggal 25 Juli 2011. STAIN Batusangkar.

Jhonson, M. H., and Everit, B. T. 1995. Essential Reproduction $\left(4^{\text {th }}\right.$ Edition). Oxford: Blackwell Scientific Ltd: 50-74.

Kohane, A. I., Pinicoro, L., and Blaqueir, J. A. 1987. Androgen controlled synthesis of specific protein in the rat epididymis. Endocrinology 112: 1590-1596.

Lufri. 2004. Pemecahan Masalah dan Peta Konsep dalam Perkuliahan Perkembangan Hewan: Analisis Sikap Mahasiswa Terhadap Pembelajaran. Jurnal Forum Pendidik 29 (02): 127-140.

Lufri. 2005. Pengaruh Pembelajaran Berbasis Problem Solving yang Diintervensi dengan Peta Konsep 
terhadap Hasil Belajar Mahasiswa. Jurnal Pembelajaran 28 (01): 4765.

Lufri. 2011. Biologi Perkembangan Hewan Jilid 2. Padang: UNP Press. (in publish)

Lufri., dan Helendra. 2009. Perkembangan Hewan Jilid 1. Padang: UNP Press.

Nerita, Siska. 2011. Pengembangan Media CD Interaktif Berorientasi Konstruktivisme Pada Pokok Bahasan Fertilisasi di Program Studi Pendidikan Biologi STKIP PGRI Sumatera Barat. Tesis Pascasarjana Universitas Negeri Padang.

Plomp, Tjeerd. 2010. Educational Design Research: An Introduction. Dalam Tjeer Plom and Nienke Nieeveen (Ed). An Introduction to Educational Design Research. (hlm9-35). Netherlands in

\section{Indeks}

analisis $1,3,4,6,9,12$

filosofis $2,5,12$

guru .2

instrumen $1,4,6$

integratif $1,3,6,7,8,12,13$

karakteristik. $1,3,7,8,9,12$

kompetensi $2,4,8,9,13$ www.slo.nl/organisatie/international/publications.

Pusat Data Akademik dan Kemahasiswaan. 2011. STAIN Batusangkar.

Sugiyono. 2007. Metode Penelitian Pendidikan, Pendekatan Kuantitatif, Kualitatif dan $\mathrm{R} \& \mathrm{D}$. Bandung: Penerbit Alfabeta.

Visconti, P. E et al. 1995. Capacitation of mouse spermatozoa, correlation between the capacitation state and protein tyrosine phosphorylation. Dev Bio 121: 1129-1150.

Wardani, G. A. K et al. 1999. Pengajaran Mikro. Padang: Pusat Sumber Belajar IKIP Padang.

Yanagimachi, R. 1994. Mammalian fertilization. In: Knobil E, Neill JD (eds.), The Physiology of Reproduction, 2nd ed. New York: Raven Press, Ltd.

membran 11,12

model $1,3,7,8,12,13$

pelajaran 2

pembelajaran $1,2,3,4,5,6,7,8,13$

Pendidikan $1,2,3,12,14,15$

spermatozoa $.10,11,12,13,14,15$ 